\title{
PEMBERDAYAAN KADER KESEHATAN DALAM PENCEGAHAN DAN PENATALAKSANAAN STUNTING PADA ANAK DI WILAYAH KERJA PUSKESMAS JATINANGOR
}

\author{
Sri Hendrawati, Fanny Adistie, dan Nenden Nur Asriyani Maryam \\ Departemen Keperawatan Anak Fakultas Keperawatan Universitas Padjadjaran \\ E-mail: sri.hendrawati@unpad.ac.id
}

\begin{abstract}
ABSTRAK. Stunting adalah masalah kurang gizi kronis yang disebabkan oleh asupan gizi yang kurang dalam waktu yang cukup lama akibat pemberian makanan yang tidak sesuai dengan kebutuhan gizi. Indonesia menduduki urutan ke-4 negara yang memiliki penderita stunting terbanyak di dunia, Jawa barat menduduki urutan ke-12 dalam posisi prevalensi stunting anak berusia di bawah lima tahun di Indonesia dengan prevalensi sebesar 29,2\% termasuk untuk wilayah Kabupaten Sumedang. Data menunjukkan bahwa di Kabupaten Sumedang, khususnya Kecamatan Jatinangor, memiliki angka kejadian stunting cukup tinggi, dan Desa Hegarmanah merupakan salah satu desa dengan tingkat stunting yang cukup tinggi di Kecamatan Jatinangor. Melalui kegiatan Pengabdian Kepada Masyarakat (PKM) Prioritas di wilayah kerja Puskesmas Jatinangor, tim pelaksana PKM melakukan pemberdayaan terhadap kader kesehatan di Kawasan Desa Hegarmanah, Jatinangor mengenai pencegahan dan penatalaksanaan stunting dengan tujuan untuk membantu kader kesehatan dalam meningkatkan pengetahuan, pemahaman, dan kewaspadaan terjadinya stunting pada anak serta bagaimana cara menanggulangi dan mengatasinya. Khalayak sasaran pada kegiatan ini adalah kader kesehatan di Desa Hegarmanah sejumlah 60 orang. Metode kegiatan ini dilakukan dengan ceramah, simulasi, diskusi, dan praktikum. Pengukuran pengetahuan pada kegiatan ini diperoleh menggunakan kuesioner pretest dan posttest, sedangkan pengukuran kemampuan psikomotor berdasarkan lembar cheklist observasi. Data dianalisis dengan distribusi frekuensi, nilai mean, dan dependent $t$-test. Hasil kegiatan menunjukkan terdapat perbedaan ratarata skor pengetahuan kader sebelum $(54,7 \pm 15,2)$ dan setelah $(66,2 \pm 16,3)$ kegiatan pemberdayaan, dengan rata-rata peningkatan skor $11,5 \pm 15,5(\mathrm{p}=0,000 ; \alpha=0,05)$. Pada kemampuan psikomotor kader menunjukkan peningkatan yang signifikan setelah dilakukan kegiatan. Melalui kegiatan ini pengetahuan dan kemampuan kader kesehatan dapat meningkat dalam pencegahan dan penatalaksanaan stunting pada anak. Hasil kegiatan ini merekomendasikan perlunya rencana tindak lanjut yaitu pencegahan dan penatalaksanaan stunting pada anak oleh kader kesehatan yang sudah dilatih dan dilakukan evaluasi secara berkelanjutan bekerjasama dengan Puskesmas Jatinangor.
\end{abstract}

Kata kunci: Anak, kader kesehatan, pencegahan dan penatalaksanaan stunting.

ABSTRACT. Stunting is a problem of chronic malnutrition caused by poor nutrition in a long time due to feeding that is not in accordance with nutritional needs. Indonesia ranks $4^{\text {th }}$ in the country that has the most stunting patients in the world, West Java ranks $12^{\text {th }}$ in the position of the prevalence of stunting of children under five years in Indonesia with a prevalence of 29.2\% including for the Sumedang Regency. Data shows that in Sumedang District, especially Jatinangor District, the incidence of stunting is quite high, and Hegarmanah Village is one of the villages with a high level of stunting in the District of Jatinangor. Through Priority Community Service (PKM) activities in the Jatinangor Community Health Center work area, the PKM implementation team empowered health cadres in the Hegarmanah Village Area, Jatinangor regarding prevention and stunting management with the aim of helping health cadres improve stunting knowledge, understanding and awareness in children and how to overcome them. The target audience for this activity was 60 health cadres in the Hegarmanah Village. The method of this activity is conducted by lectures, simulations, discussions, and practicums. Measurement of knowledge in this activity was obtained using pretest and posttest questionnaires, while measuring psychomotor ability based on observation checklist. Data were analyzed by frequency distribution, mean value, and dependent t-test. The results of the activity showed that there were differences in the average score of cadre knowledge before (54.7 \pm 15.2$)$ and after (66.2 \pm 16.3$)$ empowerment activities, with an average score increase of $11.5 \pm 15.5(p=0,000 ; \alpha=0.05)$. In psychomotor abilities cadres showed a significant increase after the activity was carried out. Through this activity the knowledge and skills of health cadres can be improved in prevention and management of stunting in children. The results of this activity recommended the need for a follow-up plan, namely prevention and management of stunting in children by health cadres who had been trained and carried out continuous evaluation in collaboration with the Jatinangor Health Center.

Key words: Children, health cadres, prevention and management of stunting.

\section{PENDAHULUAN}

Stunting menggambarkan status gizi kurang yang bersifat kronik pada masa pertumbuhan dan perkembangan sejak awal kehidupan yaitu pada masa 1000 hari pertama kehidupan (HPK) (Ni'mah \& Nadhiroh, 2015) akibat pemberian makanan yang tidak sesuai dengan kebutuhan gizi. Keadaan ini dipresentasikan dengan nilai z-score tinggi badan menurut umur (TB/U) kurang dari -2 standar deviasi (SD) berdasarkan standar pertumbuhan menurut WHO (WHO, 2010; Kemenkes RI, 2011; IDAI, 2015). Secara global, sekitar 1 dari 4 balita mengalami stunting
(UNICEF, 2013; Kemenkes RI, 2016). Kekurangan gizi pada usia dini meningkatkan angka kematian bayi dan anak, menyebabkan penderitanya mudah sakit dan memiliki postur tubuh tidak maksimal saat dewasa (UNICEF, 2012; WHO, 2010). Selain itu stunting juga menyebabkan kemampuan kognitif para penderita berkurang (UNICEF, 2012; WHO, 2010).

Indonesia merupakan negara berkembang dan termasuk kedalam sepuluh negara tertinggi dengan peringkat ke-empat jumlah balita stunting di dunia setelah India sekitar 48,3 juta, Pakistan dan Nigeria sekitar 10 juta, kemudian Indonesia yaitu sekitar 8,8 juta (WHO, 2018; Millennium 
Challenge Account-Indonesia, 2018). Di ASEAN, Indonesia menduduki peringkat kedua persentase tertinggi stunting setelah Laos $43,8 \%$, yaitu sebanyak $36,4 \%$ pada tahun 2015 (WHO, 2018). Kejadian stunting di Indonesia menurun dari tahun 2007, sebanyak $36,8 \%$ balita stunting di tahun 2007, sebanyak 35,6\% balita stunting di tahun 2010, sebanyak 37,2\% balita stunting di tahun 2013, dan sebanyak 30,8\% balita stunting di tahun 2018 (Kemenkes RI, 2018). Penurunan persentase stunting masih jauh dari sasaran RPJMN 2019 (Pembangunan Jangka Menengah Nasional) yaitu sebanyak 28\% untuk menurunkan kejadian stunting (Kemenkes RI, 2018). Meskipun persentase stunting sudah mengalami penurunan bukan berarti masalah mengenai stunting sudah teratasi (Tim Nasional Percepatan Penanggulangan Kemiskinan, 2017).

Hasil Pantauan Status Gizi (PSG) 2017 (Kemenkes RI, 2017) menunjukkan bahwa prevalensi stunting bayi berusia di bawah lima tahun (Balita) Indonesia paling banyak terjadi di NTT yaitu sebesar 40,3\%. Jawa barat sendiri berada di posisi ke-12 dengan angka stunting sebesar 29,2\%, jumlah tersebut sudah berada diatas standar stunting Indonesia yaitu 29,6\%. Menurut Sekretariat Daerah Kabupaten Sumedang (2018), Desa Hegarmanah Kecamatan Jatinangor tidak masuk dalam 10 besar penderita stunting di Sumedang. Desa yang termasuk kedalam 10 besar itu adalah Desa Cimarga, Desa Malaka, Desa Ungkal, Desa Mekarsari, Desa Cijeruk, Desa Cilembu, Desa Mekarbakti, Desa Sukahayu, Desa Margamukti, dan Desa Kebon Kalapa. Walaupun demikian, masih terdapat beberapa anak yang menderita stunting di Desa Hegarmanah berdasarkan hasil survei yang dilakukan tim pelaksana PKM di lapangan (Data Stunting Puskesmas Jatinangor, 2017). Berdasarkan data tersebut, Desa Hegarmanah merupakan desa dengan angka kejadian stunting tertinggi di Kecamatan Jatinangor. Sehingga kegiatan PKM ini dilaksanakan di Desa Hegarmanah.

Stunting berkaitan dengan peningkatan risiko kesakitan dan kematian, serta gangguan perkembangan kemampuan motorik dan mental, oleh karena itu stunting pada bayi dan balita perlu menjadi perhatian khusus (UNICEF, 2012; WHO, 2010). Pemantauan pertumbuhan khususnya panjang badan dan atau tinggi badan seharusnya dilakukan sejak bayi baru lahir untuk menilai normal tidaknya pertumbuhan anak (Bappenas RI, 2012). Deteksi dini penyimpangan pertumbuhan diperlukan untuk pemberian terapi lebih awal, sehingga memberikan hasil yang lebih baik dan mencegah terjadinya risiko yang tidak diinginkan. Masalah gizi terutama stunting pada masa ini dapat menghambat perkembangan anak, dengan dampak negatif yang akan berlangsung dalam kehidupan selanjutnya, seperti penurunan intelektual, rentan terhadap penyakit degeneratif dan tidak menular, penuruan produktivitas sehingga menyebabkan kemiskinan dan risiko melahirkan bayi dengan berat badan lahir rendah (UNICEF, 2012; WHO, 2010). Pengukuran panjang badan dan atau tinggi badan harus diukur atau dipantau secara berkala, dimulai saat bayi baru lahir, usia 1, 2, 3, 4, 5, 6 bulan dan seterusnya (WHO, 2010; IDAI, 2015).

Pemeriksaan kesehatan dan pertumbuhan anak di Desa Hegarmanah dilakukan dengan kegiatan Posyandu yang dilakukan setiap satu bulan sekali. Jumlah posyandu di Desa Hegarmanah itu sendiri ada 14 Posyandu sesuai dengan banyaknya Rukun Warga (RW) dalam desa tersebut. Selain posyandu, Kecamatan Jatinangor juga memiliki Puskesmas yang bertempat di daerah Desa Hegarmanah. Program Posyandu dilakukan di setiap desa oleh kader yang telah diberi pengetahuan dan pelatihan oleh para petugas kesehatan dari Puskesmas Jatinangor. Tujuan penggunaan kader sebagai pelaksana posyandu adalah untuk memasyarakatkan pengetahuan tentang kesehatan, salah satunya pertumbuhan dan perkembangan anak (Tim Nasional Percepatan Penanggulangan Kemiskinan, 2017). Umumnya kegiatan posyandu meliputi kegiatan penimbangan balita dan pemberian nutrisi, sehingga sebagai sasaran utama posyandu lebih tertuju pada tahap pertumbuhan fisik saja. Deteksi dini untuk mengetahui hambatan perkembangan anak juga belum diberikan, sehingga tindakan preventif untuk mengatasi adanya gangguan perkembangan pada balita belum dilakukan.

Pengabdian Kepada Masyarakat (PKM) ini dilaksanakan melalui peningkatan peran serta kader kesehatan melalui kegiatan pemberdayaan di Wilayah Kerja Puskesmas Jatinangor, khususnya Desa Hegarmanah. Melalui pemberdayaan ini diharapkan dapat meningkatkan pengetahuan, pemahaman, dan kewaspadaan kader kesehatan akan terjadinya stunting pada anak serta bagaimana cara menanggulangi dan mengatasinya. Selain itu, kedepannya juga diharapkan kader kesehatan dapat mentransferkan ilmunya kepada orangtua anak yang datang membawa anaknya ke posyandu mengenai pencegahan dan penatalaksanaan stunting ini. PKM ini dilaksanakan bekerjasama dengan Puskesmas Jatinangor dan Kader Kesehatan Desa Hegarmanah.

Kegiatan ini sebagai salah satu cara pemberdayaan kader untuk mengetahui deteksi dini dan tatalaksana stunting pada anak. Pemberdayaan kader adalah suatu strategi yang digunakan untuk meningkatkan kemampuan serta mewujudkan kemandirian kader dalam melakukan peran dan fungsinya dalam pembangunan kesehatan masyarakat (Tim Nasional Percepatan Penanggulangan Kemiskinan, 2017). Kegiatan ini diharapkan dapat memberikan kesadaran pada masyarakat Desa Hegarmanah dan kader kesehatan posyandu khususnya, bahwa stunting merupakan masalah penting yang harus ditangani bersama dengan bantuan berbagai pihak yang terkait.

Pengabdian Kepada Masyarakat (PKM) ini dilaksanakan di Wilayah Kerja Puskesmas Jatinangor dengan melibatkan mitra yaitu Puskesmas Jatinangor dan Kader Kesehatan Desa Hegarmanah. Jawa barat menduduki urutan ke-12 dalam posisi prevalensi stunting bayi berusia di bawah lima tahun di Indonesia dengan prevalensi sebesar 
29,2\% termasuk untuk wilayah Kabupaten Sumedang (Kemenkes RI, 2017). Data menunjukkan bahwa di Kabupaten Sumedang, khususnya Kecamatan Jatinangor, memiliki angka kejadian stunting cukup tinggi, dan Desa Hegarmanah merupakan salah satu desa dengan tingkat stunting yang cukup tinggi di Kecamatan Jatinangor (Data Stunting Puskesmas Jatinangor, 2017). Melalui kegiatan Pengabdian Kepada Masyarakat (PKM) Prioritas di wilayah kerja Puskesmas Jatinangor, tim pelaksana PKM melakukan pemberdayaan terhadap kader kesehatan di Kawasan Desa Hegarmanah, Jatinangor mengenai pencegahan dan penatalaksanaan stunting dengan tujuan untuk membantu kader kesehatan dalam meningkatkan pengetahuan, pemahaman, dan kewaspadaan terjadinya stunting pada anak serta bagaimana cara menanggulangi dan mengatasinya. Sehingga tujuan kegiatan ini salah satunya untuk mengidentifikasi bagaimana peningkatan kemampuan kognitif dan psikomotor kader kesehatan dalam pencegahan dan penatalaksanaan stunting pada anak. Bidang kegiatan program PKM ini yaitu berkaitan dengan bidang kesehatan dalam hal pemberdayaan kader kesehatan dalam pencegahan dan penatalaksanaan stunting pada anak di Wilayah Kerja Puskesmas Jatinangor.

\section{METODE}

Kegiatan ini berupa pemberdayaan kader kesehatan dalam pencegahan dan penatalaksanaan stunting pada anak di Wilayah Kerja Puskesmas Jatinangor. Populasi dalam penelitian ini adalah kader kesehatan di Desa Hegarmanah Kecamatan Jatinangor Kabupaten Sumedang. Teknik pengambilan sampel dengan total sampling, hal ini dilakukan agar semua kader kesehatan terpapar mengenai deteksi dini, pencegahan, dan penatalaksanaan stunting pada anak. Sehingga didapatkan 60 orang kader kesehatan yang berpartisipasi dalam kegiatan ini, yang berasal dari 14 RW di Desa Hegarmanah, masing-masing terdiri dari 4-5 orang kader kesehatan per RW. Kegiatan ini juga dihadiri oleh 2 orang petugas kesehatan dari Puskesmas Jatinangor. Kegiatan penyuluhan dilaksanakan di Aula Desa Hegarmanah dan kegiatan simulasi dilakukan di posyandu yang berada di setiap RW Desa Hegarmanah. Intervensi pemberdayaan kader kesehatan dalam kegiatan ini dilakukan melalui pemberian ceramah, simulasi, small group discussion, dan praktikum.

Kegiatan dibagi kedalam lima langkah kegiatan, yang terdiri dari:

1. Identifikasi/Pengkajian

a. Pengkajian untuk menentukan kebutuhan pelatihan pada kader kesehatan di Wilayah Kerja Puskesmas Jatinangor.

b. Pengkajian juga dilakukan untuk menentukan jumlah kelompok sasaran, yaitu kader kesehatan yang merupakan perwakilan dari seluruh RW di Desa Hegarmanah, yang berjumlah 60 orang (4-5 orang kader per RW).

\section{Penetapan masalah}

Penetapan masalah/diagnosa dirumuskan untuk memastikan bahwa apa yang akan dilakukan sesuai dengan kondisi dan kebutuhan masyarakat setempat. Penetapan masalah dilakukan dengan cara berdiskusi bersama perwakilan dari pihak Puskesmas Jatinangor yang dalam hal ini adalah Koordinator Bidang Gizi, Bidan Desa Hegarmanah, dan Koordinator Kader Kesehatan Desa Hegarmanah. Sehingga didapatkan kesepakatan untuk dilaksanakan kegiatan PKM pemberdayaan kader kesehatan dalam pencegahan dan penatalaksanaan stunting pada anak.

3. Pelaksanaan kegiatan inti

Pelaksanaan kegiatan PKM ini dilakukan dengan metode pelatihan dan pemberdayaan pada kader kesehatan mengenai pencegahan dan penatalaksanaan stunting pada anak, melalui kegiatan:

a. Pelatihan

Dalam pelatihan ini, kader kesehatan akan diberikan penjelasan mengenai konsep, deteksi dini, pencegahan, dan penatalaksanaan stunting pada anak. Pada kegiatan ini, kader kesehatan dilatih untuk melakukan deteksi dini stunting salah satunya dengan pelatihan penimbangan berat badan dan pengukuran tinggi badan anak dengan baik dan benar agar hasil pengukuran yang didapatkan akurat.

b. Pemberdayaan

Dalam pemberdayaan ini kader kesehatan didorong untuk dapat mengoptimalkan perannya dalam membantu meningkatkan derajat kesehatan masyarakat dalam hal ini kepada anak terkait pencegahan dan penatalaksanaan stunting pada anak. Kader kesehatan diharapkan dapat menerapkan ilmu yang didapatkan pada saat pelatihan pada kegiatan posyandu yang dilakukannya, diantaranya menerapkan bagaimana cara deteksi dini stunting yang salah satunya dapat dikaji dari penimbangan berat badan anak dan pengukuran panjang atau tinggi badan anak dengan baik dan benar. Kader kesehatan juga diharapkan dapat menyebarkan informasi yang didapatkan terkait stunting pada anak kepada masyarakat khususnya orangtua anak, diantaranya terkait ciri-ciri anak stunting dan bagaimana upaya untuk pencegahan dan penatalaksanaannya.

Setelah kegiatan penyuluhan, tim pelaksana PKM melakukan kegiatan pemberdayaan kader kesehatan dalam simulasi penimbangan berat badan anak dan pengukuran panjang badan atau tinggi badan anak serta simulasi kegiatan pencegahan dan penatalaksanaan stunting pada anak. Kegiatan ini dilaksanakan secara berkelanjutan sesuai dengan jadwal posyandu di setiap RW di Desa Hegarmanah bekerjasama dengan Puskesmas Jatinangor.

4. Evaluasi dan pendampingan

Untuk menilai ketercapaian tujuan maka dilakukan evaluasi melalui pendampingan dalam upaya 
kader kesehatan untuk melakukan pencegahan dan penatalaksanaan stunting pada anak serta mengoptimalkan perannya dalam pencegahan dan penatalaksanaan stunting pada anak. Kegiatan ini dilakukan dengan melakukan pendampingan kepada kader kesehatan dalam melaksanakan kegiatan posyandu. Evaluasi dilakukan terkait bagaimana kader melakukan deteksi dini stunting yang salah satunya dilakukan dengan penimbangan berat badan dan pengukuran panjang atau tinggi badan anak secara baik dan benar, serta bagaimana cara kader dalam memberikan penyuluhan kepada orangtua tentang ciri-ciri anak stunting dan pencegahan serta penatalaksanaan yang dapat dilakukan.

5. Penyusunan Rencana Tindak Lanjut (RTL)

Program pemberdayaan kader kesehatan dilakukan bekerja sama dengan Puskesmas Jatinangor karena kader kesehatan Desa Hegarmanah merupakan binaan Puskesmas Jatinangor. Program ini selanjutnya akan dilanjutkan sebagai program pendampingan dan pembinaan kader kesehatan secara berkelanjutan dan menjadi salah satu program yang akan dikembangkan di Puskesmas Jatinangor terkait pencegahan dan penatalaksanaan stunting pada anak.

Pengukuran pengetahuan pada kegiatan ini diperoleh menggunakan kuesioner pretest dan posttest. Kuesioner tersebut berisi 10 pertanyaan yang berkaitan dengan materi deteksi dini, pencegahan, dan penatalaksanaan stunting pada anak. Kuesioner terdiri dari pertanyaan dalam bentuk pilihan tunggal. Setiap jawaban benar akan mendapatkan skor 10 dan jawaban salah mendapatkan skor 0. Sehingga didapatkan nilai tertinggi 100 dan nilai terendah 0 . Sedangkan pengukuran kemampuan psikomotor berdasarkan lembar cheklist observasi. Di dalam lembar tersebut terdapat indikator keterampilan kader kesehatan dalam melakukan deteksi dini stunting. Kegiatan ini diukur dengan menggunakan lembar cheklist observasi pemeriksaan fisik untuk penimbangan berat badan dan pengukuran panjang badan atau tinggi badan anak. Pengukuran dilakukan satu kali (one shot) yaitu setelah kader kesehatan mendapatkan intervensi pemberdayaan kesehatan ini. Data dianalisis menggunakan analisis univariat dengan distribusi frekuensi dan bivariat menggunakan nilai mean dan dependent t-test karena data terdistribusi normal.

\section{HASIL DAN PEMBAHASAN}

Hasil kegiatan pada tabel 1 menunjukkan bahwa rata-rata skor pengetahuan kader kesehatan sebelum dilakukan kegiatan pemberdayaan adalah 54,7 ( $\mathrm{SD}=15,2)$, dan rata-rata skor pengetahuan kader kesehatan setelah dilakukan kegiatan adalah 66,2 (SD = 16,3), dengan ratarata peningkatan skor $11,5(\mathrm{SD}=15,5)$. Hasil uji statistik menunjukkan terdapat peningkatan yang signifikan pada pengetahuan kader kesehatan setelah dilakukan intervensi melalui pelatihan kader kesehatan dalam pencegahan dan penatalaksanaan stunting pada anak $(p=0,000 ; \alpha<0,05)$.

Tabel 1. Pengukuran Pengetahuan Kader Kesehatan dalam Pencegahan dan Penatalaksanaan Stunting pada Anak Sebelum dan Sesudah Intervensi Pemberdayaan Kader Kesehatan di Wilayah Kerja Puskesmas Jatinangor $(\mathrm{N}=60)$

\begin{tabular}{lcccc}
\hline $\begin{array}{c}\text { Pengetahuan } \\
\text { Kader } \\
\text { Kesehatan }\end{array}$ & $\begin{array}{c}\text { Rata- } \\
\text { rata }\end{array}$ & $\begin{array}{c}\text { Standar } \\
\text { Deviasi }\end{array}$ & $\begin{array}{c}\text { Nilai } \\
\text { Minimum } \\
\text { - Nilai } \\
\text { Maksimum }\end{array}$ & Nilai $\boldsymbol{p}$ \\
\hline Sebelum & 54,7 & 15,2 & $20,00-90,00$ & $0,000^{*}$ \\
Sesudah & 66,2 & 16,3 & $20,00-100,00$ & \\
\hline & & \multicolumn{4}{c}{ *Bermakna pada $\alpha<0,05$}
\end{tabular}

Tabel 2. Distribusi Frekuensi Pengukuran Kemampuan Psikomotor Kader Kesehatan dalam Pencegahan dan Penatalaksanaan Stunting pada Anak setelah Mendapatkan Intervensi Pemberdayaan Kader Kesehatan di Wilayah Kerja Puskesmas Jatinangor ( $\mathbf{N}=\mathbf{6 0})$

\begin{tabular}{lll}
\hline Kategori & Frekuensi $(\boldsymbol{f})$ & Prosentae $(\%)$ \\
\hline Baik & 60 & 100 \\
Kurang Baik & 0 & 0 \\
\hline
\end{tabular}

Selanjutnya pada tabel 2 dijelaskan kemampuan psikomotor kader kesehatan dalam melakukan pencegahan dan penatalaksanaan stunting pada anak. Berdasarkan tabel di atas, dapat dijelaskan bahwa pada kemampuan psikomotor dalam melakukan pemeriksaan fisik untuk deteksi dini stunting pada anak dalam pencegahan dan penatalaksanaan stunting pada anak menunjukkan bahwa 100\% kader kesehatan memiliki kemampuan psikomotor yang baik, artinya kader kesehatan tersebut mampu melakukan pemeriksaan fisik untuk deteksi dini stunting pada anak dalam pencegahan dan penatalaksanaan stunting pada anak.

\section{HASIL DAN PEMBAHASAN}

Hasil evaluasi pada kegiatan PKM ini menunjukkan bahwa pada saat dilakukan penyuluhan terkait konsep stunting pada anak, deteksi dini stunting pada anak, pencegahan stunting pada anak, dan penatalaksanaan stunting pada anak, semua kader sangat aktif dan antusias. Hasil skrining awal sebelum kegiatan PKM dimulai terkait pengetahuan peserta penyuluhan tentang konsep stunting pada anak, deteksi dini stunting pada anak, pencegahan stunting pada anak, dan penatalaksanaan stunting pada anak menunjukkan bahwa sebagian besar dari kader kesehatan kurang mengetahui dan memahami konsep stunting pada anak, deteksi dini stunting pada anak, pencegahan stunting pada anak, dan penatalaksanaan stunting pada anak dengan tepat dan benar. Hasil evaluasi menunjukkan bahwa terdapat peningkatan pengetahuan tentang konsep stunting pada anak, deteksi dini stunting 
pada anak, pencegahan stunting pada anak, dan penatalaksanaan stunting pada anak.

Peningkatan aspek kognitif pada kader kesehatan mengenai konsep, deteksi dini, pencegahan, dan penatalaksanaan stunting pada anak sangat penting dan menjadi salah satu tujuan dalam kegiatan ini mengingat dari berbagai penelitian yang telah dilakukan didapatkan bahwa aspek pengetahuan merupakan hal yang memengaruhi perilaku seseorang. Pengetahuan merupakan hasil dari tahu, dan ini terjadi setelah orang melakukan pengindraan terhadap suatu objek tertentu. Pengindraan terjadi melalui pancaindra manusia, yakni indra penglihatan, pendengaran, penciuman, rasa, dan raba. Sebagian besar pengetahuan manusia diperoleh melalui mata dan telinga. Pengetahuan atau kognitif merupakan domain yang sangat penting dalam membentuk tindakan seseorang (overt behavior) (Notoatmodjo, 2012), termasuk dalam hal ini tindakan kader kesehatan dalam melakukan deteksi dini, pencegahan, dan penatalaksanaan stunting pada anak.

Sebagaimana yang dinyatakan oleh Notoatmodjo, meningkatnya pengetahuan akan menimbulkan perubahan persepsi, kebiasaan dan membentuk kepercayaan seseorang. Selain itu, pengetahuan juga merubah sikap seseorang terhadap hal tertentu. Dari pengalaman dan penelitian terbukti bahwa perilaku seseorang yang didasari oleh pengetahuan, kesadaran dan sikap positif, maka perilaku tersebut akan bersifat langgeng (long lasting). Sebaliknya apabila perilaku itu tidak didasari oleh pengetahuan dan kesadaran, maka tidak akan berlangsung lama (Notoatmodjo, 2012). Begitupun dengan hasil kegiatan PKM ini, diharapkan setelah kader kesehatan mendapatkan pengetahuan tentang konsep, deteksi dini, pencegahan, dan penatalaksanaan stunting pada anak, maka kader kesehatan dapat melakukan deteksi dini, pencegahan, dan panatalaksanaan stunting pada anak.

Hasil kegiatan menunjukkan terdapat perbedaan rata-rata skor pengetahuan kader sebelum dan setelah kegiatan pemberdayaan. Peningkatan aspek kognitif, dalam hal ini pengetahuan kader kesehatan tentang konsep stunting pada anak, deteksi dini stunting pada anak, pencegahan stunting pada anak, dan penatalaksanaan stunting pada anak, merupakan salah satu tujuan pelaksanaan PKM ini. Karena berdasarkan paparan diatas, dapat disimpulkan bahwa dengan pengetahuan yang baik mengenai konsep stunting pada anak, deteksi dini stunting pada anak, pencegahan stunting pada anak, dan penatalaksanaan stunting pada anak diharapkan kader kesehatan dapat berperan dalam menanggulangi masalah stunting di masyarakat.

Selain aspek kognitif, aspek psikomotor merupakan salah satu aspek yang sangat penting bagi kader kesehatan dalam melakukan perannya sebagai salah satu sumber dukungan bagi keluarga dengan anak stunting. Aspek psikomotor merupakan aspek yang berkaitan dengan keterampilan (skill) atau kemampuan bertindak setelah seseorang menerima pengalaman belajar tertentu. Hasil belajar aspek psikomotor ini tampak dalam bentuk keterampilan (skill) dan kemampuan bertindak individu. Hasil belajar psikomotor ini sebenarnya merupakan kelanjutan dari hasil belajar kognitif (memahami sesuatu) dan hasil belajar afektif (yang baru tampak dalam bentuk kecenderungan-kecenderungan berperilaku) (Simpson, 2008).

Target aspek psikomotor yang dicapai dalam kegiatan ini kader kesehatan mampu melakukan deteksi dini stunting pada anak, pencegahan stunting pada anak, dan penatalaksanaan stunting pada anak. Hasil kegiatan menunjukkan bahwa seluruh peserta memiliki kemampuan komunikasi efektif dalam kategori baik. Selain itu, seluruh peserta PKM juga memiliki motivasi untuk melakukan deteksi dini stunting pada anak, pencegahan stunting pada anak, dan penatalaksanaan stunting pada anak. Motivasi merupakan hal yang sangat penting dan menjadi salah satu luaran dalam kegiatan ini. Motivasi adalah sebuah alasan atau dorongan seseorang untuk bertindak. Alasan atau dorongan itu bisa datang dari luar maupun dari dalam diri (Samsudin, 2005). Sebenarnya pada dasarnya semua motivasi itu datang dari dalam diri, faktor luar hanyalah pemicu munculnya motivasi tersebut (Samsudin, 2005). Motivasi dari luar adalah motivasi yang pemicunya datang dari luar diri kita. Sementara motivasi dari dalam ialah motivasinya muncul dari inisiatif diri kita. Selanjutnya, Samsudin (2005) memberikan pengertian motivasi sebagai proses memengaruhi atau mendorong dari luar terhadap seseorang atau kelompok agar mereka mau melaksanakan sesuatu yang telah ditetapkan. Motivasi juga dapat diartikan sebagai dorongan (driving force) dimaksudkan sebagai desakan yang alami untuk memuaskan dan mempertahankan kehidupan. Chung dan Megginson mendefinisikan motivasi sebagai perilaku yang dirumuskan sebagai perilaku yang ditujukan pada sasaran (Samsudin, 2005).

Setelah kegiatan ini dilakukan, diharapkan kader kesehatan dapat melakukan deteksi dini stunting pada anak, pencegahan stunting pada anak, dan penatalaksanaan stunting pada anak dalam bentuk kegiatan di posyandu ataupun kunjungan rumah. Setelah kegiatan ini dilakukan, selanjutnya akan dilakukan rencana kegiatan lain yaitu pencegahan dan penatalaksanaan stunting pada anak oleh kader kesehatan yang sudah dilatih dan dilakukan evaluasi secara berkelanjutan bekerjasama dengan Puskesmas Jatinangor. Tim pelaksana PKM akan melakukan kegiatan pemberdayaan kader kesehatan dalam simulasi penimbangan berat badan anak dan pengukuran panjang badan atau tinggi badan anak serta simulasi kegiatan pencegahan dan penatalaksanaan stunting pada anak. Kegiatan ini dilaksanakan secara berkelanjutan sesuai dengan jadwal posyandu di setiap RW di Desa Hegarmanah bekerjasama dengan Puskesmas Jatinangor.

\section{SIMPULAN}

Kegiatan PPM Prioritas ini berjalan dengan lancar atas bantuan, dukungan dan partisipasi aktif dari Puskesmas 
Jatinangor dan Desa Hegarmanah. Melalui kegiatan PPM Prioritas ini, pengetahuan dan kemampuan kader kesehatan meningkat dalam pemberdayaan kader kesehatan dalam pencegahan dan penatalaksanaan stunting pada anak di Wilayah Kerja Puskesmas Jatinangor. Selanjutnya Puskesmas Jatinangor dan Dinas Kesehatan Kabupaten Sumedang akan melakukan proses pendampingan dan pembinaan kader kesehatan secara berkelanjutan. Hasil kegiatan menunjukkan terdapat perbedaan rata-rata skor pengetahuan kader sebelum dan setelah kegiatan pemberdayaan. Pada kemampuan psikomotor kader menunjukkan peningkatan yang signifikan setelah dilakukan kegiatan. Hal ini menunjukkan bahwa kader kesehatan mampu melakukan pencegahan dan penatalaksanaan stunting pada anak. Dengan demikian maka melalui kegiatan PKM ini, pengetahuan dan kemampuan kader kesehatan dapat meningkat dalam melakukan pencegahan dan penatalaksanaan stunting pada anak.

\section{UCAPAN TERIMAKASIH}

Kegiatan Pengabdian Kepada Masyarakat Prioritas berupa Pemberdayaan Kader Kesehatan dalam Pencegahan dan Penatalaksanaan Stunting pada Anak di Wilayah Kerja Puskesmas Jatinangor ini dapat terlaksana atas fasilitasi Hibah Pengabdian Kepada Masyarakat (PKM) Prioritas yang dibiayai oleh Universitas Padjadjaran, melalui Surat Tugas Pelaksanaan Kegiatan Pengabdian Kepada Masyarakat Nomor: 800/UN6.L/PM/2018 tanggal 01 Maret 2018. Oleh karena itu, tim PKM menyampaikan ucapan terimakasih kepada semua pihak yang telah membantu pelaksanaan kegiatan ini yaitu: Rektor Universitas Padjadjaran; Direktur Riset, Pengabdian Pada Masyarakat dan Inovasi Universitas Padjadjaran beserta jajarannya; Dekan Fakultas Keperawatan Universitas Padjadjaran; Manajer Riset, Inovasi, dan Kerjasama Fakultas Keperawatan Universitas Padjadjaran; UPTD Puskesmas Jatinangor; Kepala Desa Hegarmanah; Ketua PKK Desa Hegarmanah beserta seluruh kader kesehatan; dan orangtua yang memiliki anak balita di Desa Hegarmanah.

\section{DAFTAR PUSTAKA}

Bappenas RI. (2012). Pedoman perencanaan program gerakan sadar gizi dalam rangka seribu hari pertama kehidupan (1000 HPK), p 1-8.

Data Stunting Puskesmas Jatinangor. (2017). Rekapitulasi hasil BPB tahun 2017 Puskesmas Jatinangor.

Ikatan Dokter Anak Indonesia (IDAI). (2015). Kurva pertumbuhan WHO. Diakses dari http://www.idai. or.id/professional-resources/growth-chart/kurvapertumbuhan-who.

Kementerian Kesehatan RI. (2011). Keputusan Menteri Kesehatan Republik Indonesia Nomor 1995/ Menkes/SK/XII/2010 tentang Standar Antopometri Penilaian Status Gizi Anak. Jakarta: Kementerian Kesehatan RI, Direktorat Jenderal Bina Gizi dan Kesehatan Ibu dan Anak, Direktorat Bina Gizi.

Kementerian Kesehatan RI. (2016). Situasi balita pendek. Jakarta: Kementerian Kesehatan RI, Pusat Data dan Informasi.

Kementerian Kesehatan RI. (2017). Profil kesehatan Indonesia. Jakarta. Retrieved from http://www. kemkes.go.id.

Kementerian Kesehatan RI. (2018). Hasil utama Riskesdas 2018. Jakarta.

Millennium Challenge Account - Indonesia. (2018). Stunting dan masa depan Indonesia. Jakarta: $\mathrm{MCA}$ - Indonesia.

Ni'mah, K., \& Nadhiroh, S.R. (2015). Faktor yang berhubungan dengan kejadian stunting balita. Media Gizi Indonesia, 10(1).

Notoatmodjo, S. (2012). Ilmu kesehatan masyarakat: Prinsip-prinsip dasar. Jakarta: Rineka Cipta.

Samsudin, S. (2005). Manajemen sumber daya manusia. Bandung: Pustaka Setia.

Sekretariat Daerah Kabupaten Sumedang. (2018). Hasil wawancara terkait stunting di Kabupaten Sumedang.

Tim Nasional Percepatan Penanggulangan Kemiskinan. (2017). 100 Kabupaten/Kota prioritas untuk intervensi anak kerdil (stunting). Jakarta: Tim Nasional Percepatan Penanggulangan Kemiskinan (TNP2K).

UNICEF. (2012). Ringkasan kajian gizi Oktober 2012. Jakarta: UNICEF Indonesia.

UNICEF. (2013). Improving child nutrition, the achievable imperative for global progress. New York: United Nations Children's Fund.

World Health Organization. (2010). Nutrition landscape information system: Country profile indicators. Geneva, Switzerland: World Health Organization.

World Health Organization. (2018). Reducing stunting in children: equity considerations for achieving the Global Nutrition Targets 2025. 